\title{
Pendampingan pembuatan hand sanitizer berbasis kearifan lokal (ekstrak tangkai bunga cengkeh)
}

\author{
Sundari $^{1 *}$, Dharmawaty M. Taher ${ }^{2}$, Nurhasanah $^{3}$, Abdu Mas'ud $^{4}$, Said Hasan $^{5}$ \\ 1*sundari@unkhair.ac.id, ${ }^{2}$ dharmawaty.taher@unkhair.ac.id, ${ }^{3}$ nurhasanah@unkhair.ac.id, \\ ${ }^{4}$ abdumasud@unkhair.ac.id, ${ }^{5}$ saidhasan.unk@gmail.com \\ 1,2,3,4 Prodi Pendidikan Biologi, Universitas Khairun Ternate, Indonesia
}

Received: 13 Oktober 2020

DOI: 10.29408/ab.v1i2.2697
Accepted: 26 Desember 2020 Online Published: 31 Desember 2020

URL: http://dx.doi.org/10.29408/ab.v1i2.2697

\begin{abstract}
Abstrak: Upaya untuk mencegah infeksi virus merupakan tanggng jawab bersama semua warga negara Indonesia termasuk akademisi. Pencegahan dimulai dari menjaga jarak, memakai masker, dan mencuci tangan. Salah satu alternatif lain dalam mencuci tangan adalah dengan menggunaan hand sanitizer. Program kegiatan pengabdian pada masyarakat ini bertujuan untuk mengedukasi dan membantu masyarakat dalam mencegah infeksi virus Covid-19 berbasis kearifan lokal melalui pendampingan mahasiswa dalam membuat hand sanitizer berbahan produk lokal yaitu ekstrak tangkai bunga cengkeh dan mendistribusikan produk tersebut ke masyarakat. Metode yang digunakan dalam kegiatan ini yaitu produksi, distribusi produk, dan edukasi (ceramah). Produk didistribusikan ke lingkungan kampus Universitas Khairun dan enam sekolah di kota Ternate. Hasil program pengabdian pada masyarakat ini yaitu telah diproduksi hand sanitizer berbahan dasar ekstrak tangkai bunga cengkeh sebanyak 300 botol, dan telah didistribusikan ke masyarakat. Secara umum respon masyarakat penerima produk hand sanitizer ekstrak tangkai bunga cengkeh ini adalah masyarakat antusias dan berkomentar baik terhadap produk hand sanitizer ini.
\end{abstract}

Kata kunci: Covid-19; Ekstrak Tangkai Bunga Cengkeh; Hand Sanitizer; Kearifan Lokal

Abstract: Efforts to prevent viral infection are a shared responsibility of all Indonesian citizens, including academics. Prevention starts from keeping a distance, wearing a mask, and washing hands. Another alternative to washing hands is to use a hand sanitizer. This community service activity program aims to educate and assist the community in preventing infection with the Covid-19 virus based on local culture through assisting students in making hand sanitizers made from local products, namely clove flower stem extract, and distributing them to the community. The methods used in this activity are production, product distribution, and education (lectures). The team will distribute the product to the Khairun University campus area and six schools in Ternate city. This community service program's result is 300 bottles of clove flower stalk extract and distributed to the public. In general, the community's response to the hand sanitizer product from clove flower stalk extract is that the public is enthusiastic and has good comments on this hand sanitizer product.

Keyword: Covid-19; Extract of clove flower stalks; Hand sanitizer; Local culture

\section{PENDAHULUAN}

Salah satu upaya untuk mencegah penyebaran infeksi virus Corona-19 selain melaksanakan social distancing adalah tertib untuk selalu mencuci tangan dengan sabun atau hand sanitizer. Pemakaian praktis di luar rumah adalah dengan pemakaian hand sanitizer. Namun pada saat ini produk hand sanitizer sudah mulai langka dan harganya mahal (Saraswati, 2020). Organisasi Kesehatan Dunia atau World Health Organization (WHO) menjelaskan salah 
satu cara pencegahan penyebaran virus Corona adalah dengan membersihkan tangan secara teratur, memakai cairan antiseptik pembersih tangan (hand sanitizer) yang mengandung alkohol atau mencuci tangan dengan sabun dan air mengalir (Tamtomo, 2020). Pada saat pandemik Covid-19 kebutuhan antiseptic dan hand sanitizer sebagai bahan pencegahan infeksi Covid-19 menjadi utama (Nakoe, dkk., 2020).

Pada saat ini, dunia telah dilanda pandemic virus corona, termasuk Indonesia. Sejak diumumkannya pasien positif oleh presiden Joko Widodo sampai saat ini angka pertambahan ODP, dan PDP terus meningkat. Angka kematian di Indonesia tergolong tinggi karena mencapai kurang lebih 8,58\% (Farisa, 2020). Pandemi corona di Indonesia di mulai dari Jakarta dan sekitarnya selanjutnya menyebar di beberapa propinsi termasuk Maluku Utara.

Pada bulan April 2020 perkembangan kasus Covid-19 di Maluku Utara menjadi ODP 333 orang, OTG 75 orang (Kominfo, 2020). Petugas gugus Covid-19 di Maluku Utara selalu melaporkan update jumlah ODP dan PDP di Maluku Utara. Pada awalnya dari sejumlah 3 orang PDP 1 orang dinyatakan positif. Kondisi ini menuntut komitmen kita selaku masyarakat untuk mengikuti arahan pemerintah dengan menjaga social distancing dan rajin mencuci tangan baik dengan sabun ataupun hand sanitizer.

Salah satu upaya yang telah dilakukan prodi Pendidikan Biologi FKIP universitas Khairun adalah dengan membuat hand sanitizer pada matakuliah Bioteknologi. Formula hand sanitizer yang dikembangkan adalah hand sanitizer berbahan alami dari ekstrak tangkai bunga cengkeh dan alkohol 70\%. BPOM dalam surat edarannya telah memiliki standar bahan pembuatan hand sanitizer yaitu Etanol 96\%, Gliserol 98\%, Hidrogen Peroksida 3\%, dan air steril atau Aquadest (BPOM, 2020). Akan tetapi pada saat itu bahan-bahan tersebut mengalami kelangkaan, sehingga dimanfaatkan bahan lokal yaitu ekstrak tangkai bunga cengkeh dapat meminimalisir kendala bahan alkohol 98\% diganti alkohol 70\% karena ekstrak tangkai cengkeh banyak mengandung fenol dan alkohol (Wahyuni, 2020). Selain itu esensial oil dan peroksida tidak diperlukan lagi karena ekstrak tangkai cengkeh memiliki aroma khas dan kuat. Ekstrak cengkeh juga memiliki kandungan eugenol yang tinggi dan secara invitro dapat menghambat pertumbuhan mikroorganisme (Utami, dkk., 2019). Penggunaan alkohol berkadar lebih dari 60\% secara terus menerus dapat mengakibatkan kerusakan pada lapisan kulit (Wijaya, 2013). Sehingga diperlukan zat atau unsur lain untuk menetralisir hal tersebut, dalam hal ini menggunakan ekstrak tangkai bunga cengkeh.

Berdasarkan analisis situasi di atas maka dapat dilaksanakan langkah dan solusi terhadap permasalahan yang terjadi yaitu melaksanakan kegiatan produksi hand sanitizer dengan menggunakan bahan dasar eugenol ekstrak tangkai bunga cengkeh dan alkohol $70 \%$ serta bahan alam lainnya. Produksi masal hand sanitizer berbahan alam ini akan dibagikan pada masyarakat. Produksi masal hand sanitizer ini diharapkan dapat membantu pemenuhan bahan antiseptic pensanitasi tangan sebagai upaya mencegah infeksi virus corona.

Kegiatan PKM ini bertujuan untuk membantu masyarakat dalam mencegah infeksi virus Covid-19 berbasis kearifan lokal melalui pendampingan mahasiswa dalam membuat hand sanitizer berbahan produk lokal yaitu ekstrak tangkai bunga cengkeh, dan mendistribusikan hasil produksi tersebut ke masyarakat kota Ternate serta mengedukasi masyarakat tentang cara mencegah penyebaran virus Covid-19 


\section{METODE PELAKSANAAN}

\section{Waktu dan tempat}

Program ini akan berlangsung selama 8 bulan yaitu dari bulan April sampai dengan Oktober 2019. Lokasi kegiatan pengabdian produksi hand sanitizer di Laboratorium Biologi Universitas Khairun Ternate dan pembagian produk pada masyarakat sekolah TK, SD, SMP, SMA dan masyarakat umum di kota Ternate

\section{Prosedur pelaksanaan}

1. Tahap Persiapan

Persiapan alat dan bahan serta komposisi hand sanitizer, dan persiapan peserta serta tempat pelatihan

2. Produksi Hand sanitizer

a. Melibatkan 3 orang dosen dan 2 orang mahasiswa pendidikan biologi

b. Pendampingan mahasiswa dalam produksi hand sanitizer oleh dosen

3. Pendampingan dan sosialisasi produk dengan membagikan hand sanitizer pada masyarakat, agar membiasakan diri mencuci tangan atau membersihkan tangan dengan dengan hand sanitizer khususnya di sekolah. Pada saat membagikan produk dilakukan simulasi menjaga kebersihan tangan sebagai upaya pencegahan penularan covid 19.

4. Evaluasi dan persiapan tindak lanjut, melalui pemberian feedback atau umpan balik dari masyarakat yang menggunakan produk hand sanitizer.

\section{HASIL DAN PEMBAHASAN}

\section{Hasil}

Pada tahap persiapan dosen dan mahasiswa mempersiapkan bahan-bahan untuk pembuatan hand sanitizer. Antara lain alkoho 70\%, gliserin dan ekstrak tangkai bunga cengkeh. Sebelum pencampuran dilakukan, dosen terlebih dahulu mendampingi mahasiswa dalam pembuatan ekstrak tangkai bunga cengkeh. Dosen mengarahkan dan memberi petunjuk mengenai takaran bahan-bahan yang digunakan.

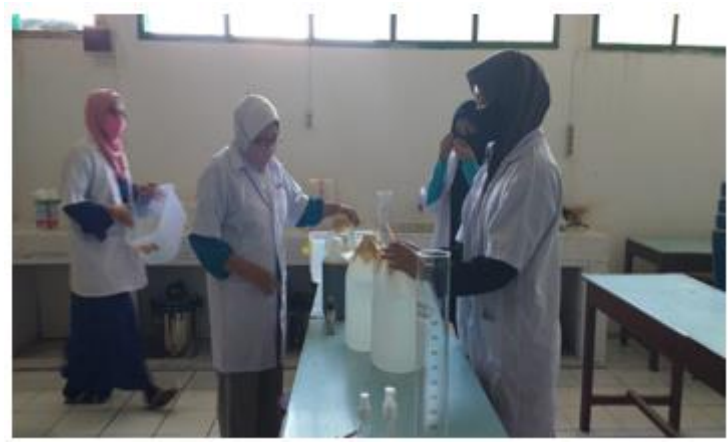

Gambar 1. Dosen mendampingi mahasiswa membuat ekstrak tangkai bunga cengkeh

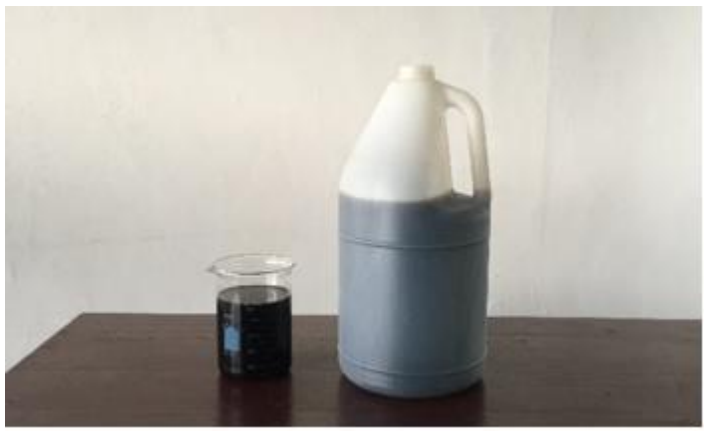

Gambar 2. Hasil pengekstrakan tangkai bunga cengkeh

Setelah hasil pengekstrakan tangkai bunga cengkeh didapatkan, kemudian dilakukan pencampuran antara ekstrak tangkai bunga cengkeh dengan alkohol 70\%, gliserin, dan maserasi 
kayu sabo yang mengandung vit. E, dengan komposisi 600ml alkohol, $400 \mathrm{ml}$ ekstrak tangkai bunga cengkeh, $20 \mathrm{ml}$ gliserin dan 10gram kayu sabo.

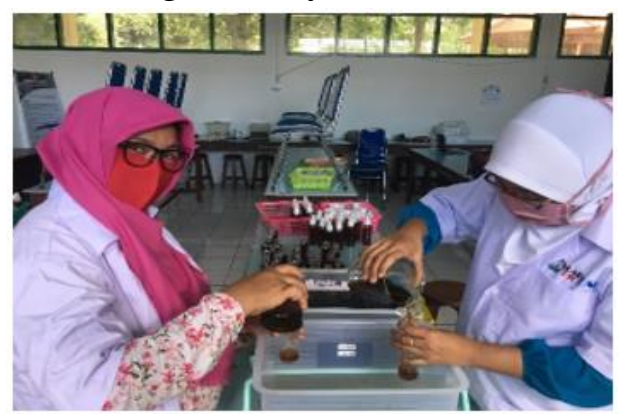

Gambar 3. Pencampuran semua bahan

Setelah hasil pencampuran didapatkan selanjutnya ke tahap pengemasan dan labeling produk.

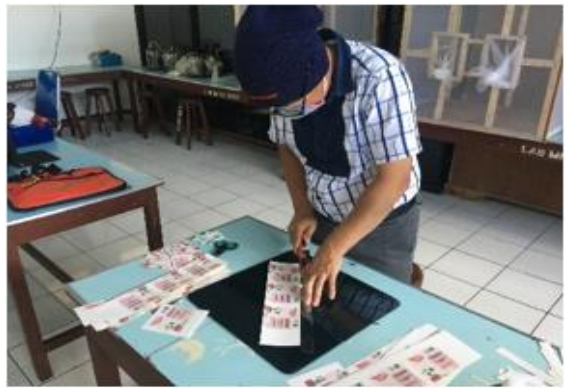

Gambar 4. Persiapan Labeling
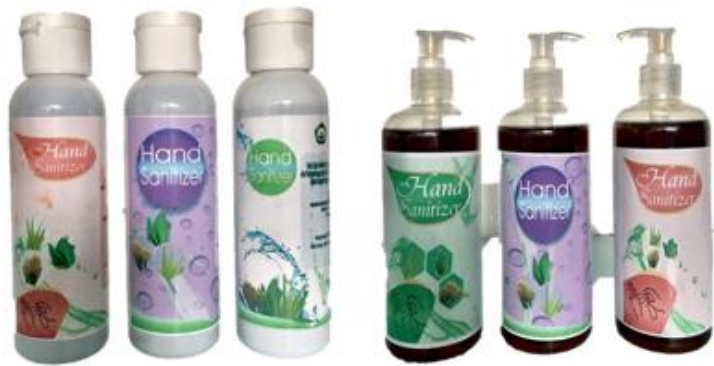

Gambar 5. Produk akhir hand sanitizer ekstrak tangkai bunga cengkeh

Setelah produksi selesai, didapatkan hasil produksi sejumlah 300 botol hand sinitizer. Kemudian produk ini didistribusikan ke 6 (enam) lokasi di kota ternate, yaitu di fakultas FKIP, Pasca sarjana, LPPM, Fakutas Sastra, Fakultas Perikanan, dan sekolah PAUD, TK, SD, SMP dan SMA di kota Ternate. Selain mendistribusikan produk hand sinitizer, dilakukan juga edukasi tentang pola hidup sehat di lokasi-lokasi tempat penyebaran produk.
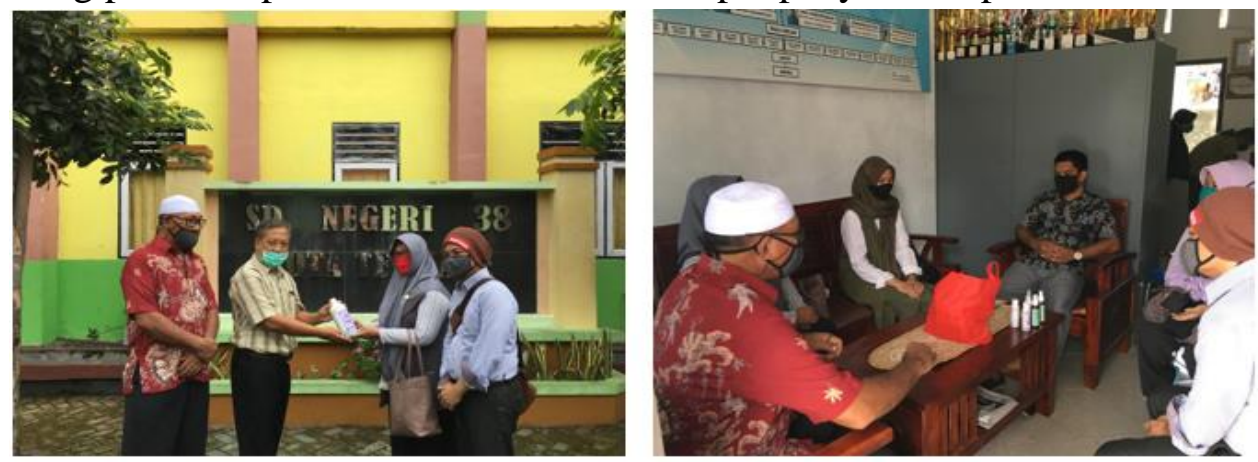

Gambar 6. Penyebaran produk dan edukasi hidup sehat di salah satu SD di kota ternate 

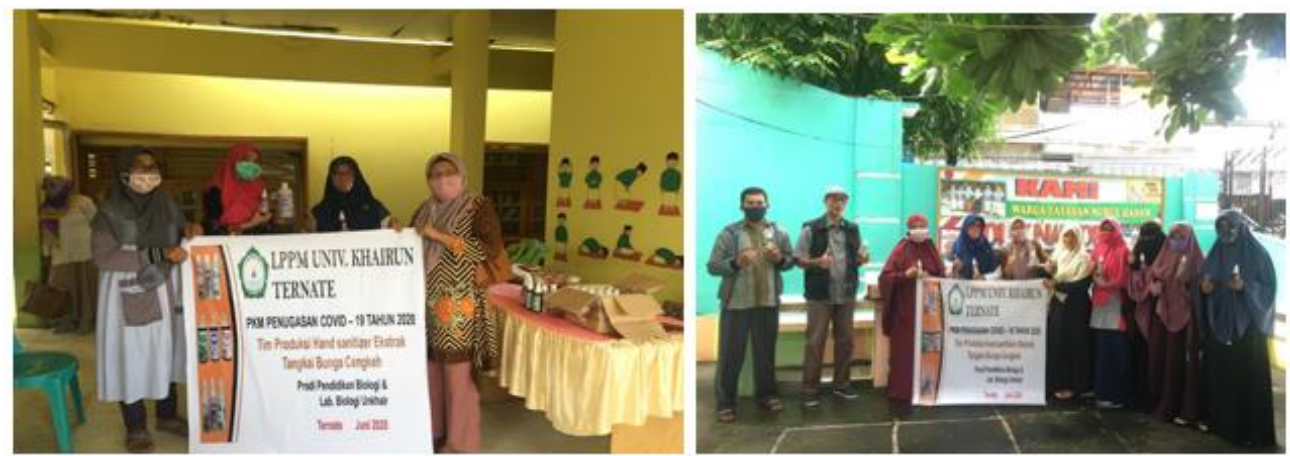

Gambar 7. Penyerahan Produk Hand sanitizer di Sekolah TK dan PAUD

Tahap selanjutnya yaitu evaluasi pengembangan produk hand sanitizer berbahan dasar ekstrak tangkai bunga cengkeh. Evaluasi dilakukan dengan cara uji tingkat penerimaan produk (Fikriawan, 2019). Berdasarkan hasil analisis tingkat hasil penerimaan masyarakat di kota Ternate terhadap produk hand sinitizer berbahan baku ekstrak tangkai bunga cengkeh diperoleh persentase sebesar:

\section{Persentase Tingkat Penerimaan Masyarakat Terhadap Hand Sinitizer Ekstrak Tangkai Cengkeh}

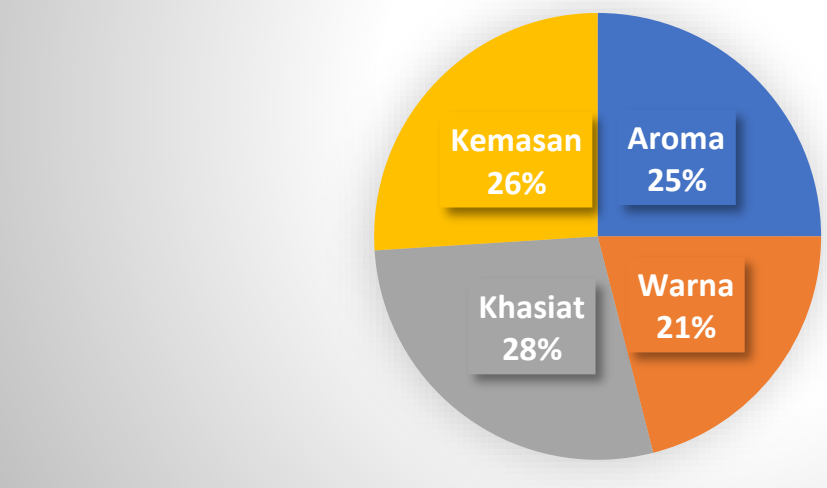

$$
\begin{aligned}
& \text { Aroma } \\
& \text { Warna } \\
& \text { Khasiat } \\
& \text { Kemasan }
\end{aligned}
$$

Gambar 8. Preferensi konsumen terhadap produk Hand sanitizer

Berdasarkan Gambar 6 diketahui bahwa produk Hand sanitizer berbahan ekstrak tangkai bunga cengkeh disukai oleh konsumen sebagai produk Hand sanitizer yang layak digunakan berdasarkan kriteria warna, aroma, khasiat, kemasan.

\section{Pembahasan}

Pendampingan pembuatan produk hand sinitizer berbahan dasar ekstrak tangkai bunga cengkeh yang dihasilkan dalam kegiatan ini berjalan dengan lancar, seperti yang telah direncanakan sebelumnya. Kualitas produk hand sinitizer berbahan dasar ekstrak tangkai bunga cengkeh yang dihasilkan mampu menggantikan produk-produk lain yang sejenis, karena ekstrak tangkai bunga cengkeh dapat menjadi pengganti alkohol dan triklosan serta parfum. Meskipun bahan yang digunakan tidak sesuai dengan kententuan dari BPOM, akan tetapi dari 
selama pengujian hasil produksi, produk mampu memiliki kasiat yang sama dengan produk yang lainnya.

Tingkat penerimaan masyarakat akan produk ini juga sangat baik. Sekolah-sekolah dan lingkungan kampus sangat antusias dalam menerima produk ini. Dari segi edukasi, masyarakat dapat mengetahui cara hidup sehat dan memiliki pengetahuan bahwa bahan alami seperti cengkeh juga mampu untuk mengatasi penyebaran virus Covid-19. Sehingga kedepannya masyarakat lebih dapat mawas diri untuk menjaga kesehatan

\section{KESIMPULAN}

Berdasarkan hasil pendampingan pembuatan dan pendistribusian produk hand sinitizer ke masyarakat dapat disimpulkan bahwa tujuan dari kegiatan pengabdian pada masyarakat ini berhasil didapatkan dengan baik. Pendistribusian produk hand sinitzer ke masyarakat mampu membantu masyarakat dalam mencegah penyebaran virus Covid-19. Produk ini dapat diterima dan digunakan oleh masyarakat di kota Ternate.

\section{PERNYATAAN PENULIS}

Artikel ini merupakan hasil program pengabdian kepada masyarakat masa pandemik Covid-19 di Maluku Utara. Tulisan ini belum pernah dipublish pada jurnal lain.

\section{UCAPAN TERIMAKASIH}

Tim pelaksana PKM penugasan Covid-19 dengan judul Pembuatan Hand sanitizer berbahan dasar tangkai bunga cengkeh mengucapkan terimakasih kepada LPPM Universitas Khairun Ternate yang telah memberikan suport dana untuk kegiatan ini.

\section{DAFTAR PUSTAKA}

Farisa, F. C. (2020, April 19). UPDATE 18 April: 6.248 Kasus Covid-19 di Indonesia, Persentase Kematian 8,56 Persen. Retrieved from Kompas.com: https://nasional.kompas.com/read/2020/04/19/07123281/update-18-april-6248-kasuscovid-19-di-indonesia-persentase-kematian-856?page=all

Fikriawan, W. (2019). Uji Mutu Fisik Dan Penerimaan Volunter Gel Handsanitizer air Perasan Pelepah Pisang Kepok (Doctoral dissertation, Akademi Farmasi Putra Indonesia Malang)

Kominfo, A. (2020, April). Diskominfosan Malutprov. Retrieved from Web Resmi Pemprov Maluku Utara: https://malutprov.go.id/gugus-tugas--covid19-malut-menggelar-rapidtest

Nakoe, R., Lalu, N. A. S., \& Mohamad, Y. A. (2020). Perbedaan Efektivitas Hand-Sanitizer Dengan Cuci Tangan Menggunakan Sabun Sebagai Bentuk Pencegahan Covid19. Jambura Journal of Health Sciences and Research, 2(2), 65-70.

Saraswati, P. D. (2020, April). Polri: Masker-Hand Sanitizer Langka karena Permintaan Tinggi. Retrieved from CNN Indonesia: https://www.cnnindonesia.com/nasional/20200324163937-12-486574/polri-maskerhand-sanitizer-langka-karena-permintaan-tinggi 
Surat Edaran Badan Pengawas Obat dan Makanan Nomor KP.11.01.2.83.20.14 tentang Pembuatan Hand Sanitizer dalam Upaya Mencegah Virus Corona. (2020). Jakarta: Badan POM Republik Indonesia

Tamtomo, A. B. (2020, Maret 20). INFOGRAFIK: Cara Buat Hand Sanitizer Versi WHO. Retrieved from Kompas.com: https://www.kompas.com/tren/read/2020/03/18/183000265/infografik--cara-buathand-sanitizer-versi-who

Utami, R. T., Dewi, S. S., \& Darmawati, S. (2019). Aktivitas Antibakteri Ekstrak Batang Cengkeh (Syzigium aromaticum) terhadap Pertumbuhan Bakteri Methicillin-Resisten Staphylococcus aureus (MRSA). In Prosiding Seminar Nasional Mahasiswa Unimus (Vol. 2).

Wahyuni, N. A. (2020). Uji aktivitas antibakteri ekstrak bunga cengkeh (Syzygium aromaticum) terhadap Klebsiella pneumoniae secara in vitro (Doctoral dissertation, Universitas Islam Negeri Maulana Malik Ibrahim).

Wijaya, J. I. (2013). Formulasi Sediaan Gel Hand Sanitizer Dengan Bahan Aktif Triklosan 1, $5 \%$ dan 2\%. Calyptra, 2(1), 1-14. 